\title{
Sensory disturbances, inhibitory deficits, and the P50 wave in schizophrenia
}

\author{
This article was published in the following Dove Press journal: \\ Neuropsychiatric Disease and Treatment \\ 14 July 2014 \\ Number of times this article has been viewed
}

\section{Premysl VIcek' \\ Petr Bob ${ }^{1,2}$ \\ Jiri Raboch'}

'Center for Neuropsychiatric Research of Traumatic Stress, Department of Psychiatry and UHSL, First Faculty of Medicine, Charles University, Prague, Czech Republic; ${ }^{2}$ Central European Institute of Technology (CEITEC), Masaryk University, Brno, Czech Republic

Correspondence: Petr Bob Center for Neuropsychiatric Research of Traumatic Stress, Department of Psychiatry and UHSL, First Faculty of Medicine, Charles University, Prague, Czech Republic Email petrbob@netscape.net

\begin{abstract}
Sensory gating disturbances in schizophrenia are often described as an inability to filter redundant sensory stimuli that typically manifest as inability to gate neuronal responses related to the P50 wave, characterizing a decreased ability of the brain to inhibit various responses to insignificant stimuli. It implicates various deficits of perceptual and attentional functions, and this inability to inhibit, or "gate", irrelevant sensory inputs leads to sensory and information overload that also may result in neuronal hyperexcitability related to disturbances of habituation mechanisms. These findings seem to be particularly important in the context of modern electrophysiological and neuroimaging data suggesting that the filtering deficits in schizophrenia are likely related to deficits in the integrity of connections between various brain areas. As a consequence, this brain disintegration produces disconnection of information, disrupted binding, and disintegration of consciousness that in terms of modern neuroscience could connect original Bleuler's concept of "split mind" with research of neural information integration.
\end{abstract}

Keywords: event-related potential, information overload, inhibition, P50 wave, schizophrenia, splitting

\section{Introduction}

Sensory disturbances in schizophrenia are often described as an inability to filter meaningful sensory stimuli. ${ }^{1-9}$ In experimental settings, this filtering inability has been examined most often using auditory evoked potentials to repeated sounds with the main aim of testing the brain's ability to inhibit (or gate) its response to repeated stimuli that in schizophrenic patients typically manifest as an inability to gate neuronal responses related to the P50 wave. ${ }^{10-12}$

According to recent findings, sensory gating abnormalities represent early clinical symptoms of schizophrenia, typically characterized as a decreased ability of the brain to inhibit various responses to insignificant stimuli., ${ }^{1,5,13-18}$ Typical symptoms manifest as hypervigilance and difficulty in focusing attention, most likely due to disturbances of inhibitory neuronal activity in the hippocampus related to deficits of nicotinic cholinergic modulation..$^{717,19,20}$ Typically, the gating related to the P50 wave is linked to widely distributed neuronal activities involving the temporoparietal and prefrontal cortical networks, mainly during the early phases of processing, in which a very significant role is played by the CA3-CA4 area of the hippocampus and its cholinergic inputs from the septal nucleus mediated by low-affinity nicotinic receptors affecting CA3-CA4 interneurons. ${ }^{21-24}$ These gamma aminobutyric acid (GABA)ergic interneurons transiently inhibit pyramidal neurons and mediate gating of the second stimulus during sensory stimulation usually used in event-related potential experiments. ${ }^{25-28}$ In this context, the basic experimental finding in research of auditory P50 sensory gating is typically suppression of the response to the second identical 
(S2) stimulus presented shortly after the first (S1) stimulus. This event-related potential response manifests very early in information processing (about 50 milliseconds) and most likely represents an adaptive mechanism preventing from becoming overloaded by redundant sensory information from the environment. ${ }^{29-31}$

These typical inhibitory deficits related to activity of pyramidal neurons in the CA3 region of the hippocampus were therefore identified as important contributors to the cerebral evoked responses that play a significant role in habituation of repeated stimuli depending on cholinergic stimulation of hippocampal inhibitory interneurons. ${ }^{27}$ Because of this cholinergic stimulation, those interneurons manifest bursts of activity that release a sufficient amount of GABA to activate presynaptic GABA-B receptors on CA3 pyramidal neurons, and due to this release, the excitatory neurotransmitter glutamate is blocked, so that the CA3 pyramidal neurons cannot respond to the second stimulus. ${ }^{27,28,32}$

Current experimental and theoretical findings of normal responses to repeated auditory stimuli at the single neural level in animal models have provided some direct insights into the basic mechanisms of the sensory gating deficits. ${ }^{21}$ Basic observations show that acetylcholine receptors on hippocampal interneurons are very sensitive to alpha bungarotoxin, a nicotinic antagonist. ${ }^{23,32}$ Specific roles for these lowaffinity nicotinic receptors in the P50 gating abnormalities in schizophrenia are supported by various recent physiological, pharmacological, and genetic studies. ${ }^{17,19,33-41}$ For example, these data show that the flow of sensory information from the cortex to the hippocampus is controlled by nicotinic cholinergic input from the septum to the hippocampus. ${ }^{32,42}$ These findings are also supported by genetic studies indicating that nicotinic receptors (produced by the specific alpha-7nicotinic acetylcholine receptor subunit gene, CHRNA7) influence inhibition of responses to repeated auditory stimuli. ${ }^{7,21,23,35,43,44}$ In addition, several studies show that these sensory gating disruptions are also influenced by alpha-2selective noradrenergic antagonists (eg, yohimbine) and 3-methoxy-4-hydroxyphenylglycol. ${ }^{45-49}$ Altogether, these findings indicate that specific inhibitory deficits play a major role in sensory gating deficits that can be observed in eventrelated potential studies focused on the P50 wave.

\section{P50 and inhibitory theory}

According to physiological theory, the main events enabling a decreased evoked response due to repetition of identical stimuli are linked to active inhibitory/excitatory mechanisms and passive habituation/dishabituation mechanisms. A basic explanation of this active gating theory suggests that local neuronal inhibitory activity of the $\mathrm{S} 1$ stimulus specifically inhibits and filters out the response to the S2, representing the second identical stimulus (the same as the previous one). ${ }^{50-54}$

The second stimulus therefore has no new information and is inhibited. The inhibitory effect of the stimulus, which usually lasts several hundred milliseconds, develops inhibitory postsynaptic potentials at about $96 \%$ of neurons in the primary auditory cortex in the early period of the inhibitory response (20-200 msec). During this period of inhibitory postsynaptic potentials, neural membrane resistance is reduced to $60 \%-90 \%$ of its initial value. In the subsequent periods, the efficiency of inhibitory reactions typically decreases for periods lasting longer than $200 \mathrm{msec}$. In this context, it is likely that the decreased neuronal sensitivity to auditory stimuli repeated every $500 \mathrm{msec}$ is caused by inhibitory processes in cortical neurons per se rather than their blocking due to "in-flow" of afferent excitatory impulses during the refractory period. ${ }^{55,56}$

Any following inputs reset the cortical dynamics with a delay that ranges from 10 to several hundred milliseconds, enabling cortical mechanisms to process rapidly changing successive information in short time intervals. ${ }^{57-59}$ For example, Volkov and Galazyuk ${ }^{57}$ in a more general context proposed that synchronous activations of a large number of cortical neurons by a short stimulus resulted in coordinated release of a large amount of inhibitory transmitters into the synaptic connections, enabling relatively prolonged hyperpolarization of post-synaptic neurons.

As a consequence, a repeated stimulus leads to constant release of a small amount of neurotransmitter into the synaptic cleft, which may explain the process of continued inhibition. To explain this mechanism, it has also been proposed that the $\mathrm{S} 1$ stimulus may influence the initial evoked response that excites the hippocampal pyramidal neurons and also activate the inhibitory neurons that act as a comparator, and via this mechanism, the subsequent identical S2 stimulus produces diminished responses, when pyramidal neurons acting as the comparator are still active. On the other hand, when a subsequent nonidentical stimulus is presented, different sets of neurons are stimulated that were not stimulated before, resulting in an unhabituated response. ${ }^{60-66}$

The current evidence also suggests that the main generators of P50 are located in the temporal lobes, but the main neuronal activities contributing to amplitude reduction in the P50 time range are localized in the frontal lobe ${ }^{67}$ These processes are closely linked to those of memory reconsolidation, 
typically involving the medial temporal and frontal lobes that interact closely to allow successful remembering of and responses to sensory stimuli. Whereas the medial temporal lobe is predominantly associated with encoding, storage, and retrieval of long-term memories, the prefrontal cortex is closely related to cognitive control processes such as selection, engagement, monitoring, and inhibition. ${ }^{68}$

\section{P50 in schizophrenia}

Recent findings indicate that schizophrenia is characterized by typical disturbances in cognitive processes that predominantly manifest as deficits of perceptual and attentional function. ${ }^{69-75}$ In this context, the data suggest that these deficits are characterized by an inability to inhibit, or "gate", irrelevant sensory inputs, leading to the sensory and information overload typical of individuals with schizophrenia. ${ }^{1,76-82}$ This sensory gating deficit may result in neuronal hyperexcitability due to disturbances of neuronal inhibition at the subcortical and cortical levels. 5,33,60,83 Accordingly, typical cognitive and sensory processing deficits in schizophrenia are closely related to deficits in P50 auditory gating which are linked to nicotinic cholinergic-mediated disinhibitory processes, representing a new potential opportunity for therapeutic intervention in schizophrenia. ${ }^{40,41,43,44,84-89}$

The data presented above strongly suggest that patients with schizophrenia manifest typical disturbances of habituation mechanisms linked to information overload, leading to disruption of information processing. ${ }^{90-94}$ In this context, many studies have shown that the P50 sensory gating ratio in a paired click task is higher in patients with schizophrenia than in healthy controls, indicating more effective sensory gating processes. ${ }^{37,47,61,88,89,95-113}$

A detailed meta-analysis ${ }^{8}$ rejected the possibility of the null hypothesis that these studies showed no effect, and also found that the differences were not the same across all studies. In this meta-analysis, the mean ratios in 45 of 46 group comparisons were smaller for controls than for patients. Patterson et $\mathrm{al}^{8}$ have also shown that the observed differences in means were significant in 35 of these studies. They identified 46 studies suitable for analysis of P300 measures, including 1,443 patients and 1,251 controls. There were 20 P50 studies, including 421 patients and 401 controls. The pooled standardized effect size (the difference between the means of the two groups divided by the common standard deviation) for the P50 ratio was -1.56 (95\% confidence interval $-2.05,-1.06$; $P<0.001)$. There were no significant differences between patients and controls in P50 latency. Across-study variations in filters, task difficulty, antipsychotic medication, and duration of illness did not influence the pooled standardized effect size significantly. Patterson et $\mathrm{al}^{8}$ concluded that their meta-analysis confirms the existence of event-related potential deficits in schizophrenia, with significance similar to the most robust findings reported in neuroimaging and neuropsychology in schizophrenia. Similar conclusions found also several others meta-analytic or detailed review studies which show sensory gating impairments in early stages of schizophrenia that become more prominent in chronic stages of schizophrenia. ${ }^{8,11,13,15,114}$ Further meta-analytical data by Chang et $\mathrm{al}^{115}$ confirm that the sensory gating deficit in patients with schizophrenia is well documented; nevertheless, certain findings raise doubts about the validity and utility of the $\mathrm{S} 2 / \mathrm{S} 1$ ratio as a measure of sensory gating. The meta-analytical results confirm that the $\mathrm{S} 2 / \mathrm{S} 1$ ratio and the repeating (S2) stimulus discriminate effectively between patients with schizophrenia and healthy controls, in contrast with the consistent but smaller effect size for the S1 amplitude, and these findings likely reflect inhibitory deficits related to repeated redundant input. Future studies are needed to clarify in detail the variables modifying sensory gating processes related to progression of schizophrenia and genetic predisposition to the illness. ${ }^{13,113,116}$

In this context, recent findings also show that schizophrenia is associated with impairments of functional brain connectivity, which in principle may be studied using the P50 suppression paradigm in close relationship with the functional integrity of connections between brain areas involved in cross-sensory processing. According to a study reported by Magnee et $\mathrm{al}^{117}$ the typical filtering deficits studied as P50 deficits may be secondary to earlier sensory dysfunctions due to deficits in the integrity of connections between brain areas involved in low-level cross-sensory processing. In principle, this finding is in agreement with data suggesting that the main generators of P50 are located in the temporal lobes but that the neuronal activities predominantly contributing to amplitude reduction in the P50 time range are localized in the frontal lobe. ${ }^{67}$

This relationship between connectivity and P50 in schizophrenia is also in agreement with the finding that gamma and beta activity, which are likely to be specifically linked to neural synchrony, connectivity, and integration of information, are related to P50. In this context, the initial response to $\mathrm{S} 1$ is observed as a high gamma band oscillatory activity that after about $200 \mathrm{msec}$ switches to beta frequency oscillations, which may reflect an encoding of the sensory perception. ${ }^{118-121}$ There is also some interesting evidence showing that this post-S1 beta frequency response 
is inversely correlated with the $\mathrm{S} 2$ response in patients with schizophrenia. ${ }^{100,106,122}$ This suggests that P50 is basically linked to rhythmic activity of neural assemblies that code information processing within and across cortical circuits and modulate neuronal excitability. ${ }^{120,123-126}$

Based on these findings, sensory gating deficits related to schizophrenia might be explained by disconnection of information, mainly between temporal lobe generators and the frontal lobe, which may account for the diminished inhibitory activity of the frontal cortex linked to the P50 deficit.

\section{Conclusion}

There is now growing evidence that disruption of coherent neural binding is related to disintegration of consciousness in schizophrenia, ${ }^{127-130}$ and that this could be related to sensory gating disturbances. ${ }^{127}$ In this context, sensory gating research might yield new findings connecting neuroscientific and psychological research of schizophrenia that could connect "split mind" according to original Bleuler's concept with research of disturbed integration in neural information processing. Together these findings suggest that mental disintegration in schizophrenia could be described as sensory and information disturbance related to disinhibition and neural disintegration.

Major findings supporting the need for future research in this area include data indicating that long-range synchrony of gamma oscillations reflecting neural connectivity that depends on excitatory postsynaptic potentials of GABAergic interneurons is also closely related to sensory gating processes. ${ }^{28,32,126}$ This relationship between gamma oscillations and GABAergic interneurons is especially important for investigation of schizophrenia, given that there is now evidence indicating disturbance of GABAergic interneurons in schizophrenia. ${ }^{127-129}$ Further, convergent findings indicate that a signaling deficiency leads to reduced GABA synthesis and disrupted coordination of neural representations and related changes in perception and cognition in patients with schizophrenia. ${ }^{127,129,130}$ There is also evidence that these GABAergic abnormalities play an important role in schizophrenia and that the changes in neural synchrony in schizophrenia are most likely linked to dysregulation of multiple neurochemical systems, also including glutamate, dopamine, and other neurotransmitter molecules.

\section{Acknowledgments}

This study was supported by grants from the Charles University (PRVOUK and SVV), the Czech Ministry of Education (LH11032), and the Central European Institute of Technology (CZ.1.05/1.1.00/02.0068), and the European Regional Development Fund.

\section{Disclosure}

The authors report no conflicts of interest in this work.

\section{References}

1. McGhie A, Chapman J. Disorders of attention and perception in early schizophrenia. Br J Med Psychol. 1961;34:103-116.

2. Venables PH. Input dysfunction in schizophrenia. Prog Exp Pers Res. 1964;72:1-47.

3. Saccuzzo DP, Braff DL. Early information processing deficit in schizophrenia. New findings using schizophrenic subgroups and manic control subjects. Arch Gen Psychiatry. 1981;38:175-179.

4. Johnson JD. A mechanism to inhibit input activation and its dysfunction in schizophrenia. Br J Psychiatry. 1985;146:429-435.

5. Freedman R, Adler LE, Gerhardt GA, et al. Neurobiological studies of sensory gating in schizophrenia. Schizophr Bull. 1987;13: 669-678.

6. Freedman R, Adler LE, Olincy A, et al. Input dysfunction, schizotypy, and genetic models of schizophrenia. Schizophr Res. 2002;54: $25-32$.

7. Freedman R, Olincy A, Ross RG, et al. The genetics of sensory gating deficits in schizophrenia. Curr Psychiatry Rep. 2003;5:155-161.

8. Patterson JV, Hetrick WP, Boutros NN, et al. P50 sensory gating ratios in schizophrenics and controls: a review and data analysis. Psychiatry Res. 2008;158:226-247.

9. Olincy A, Braff DL, Adler LE, et al. Inhibition of the P50 cerebral evoked response to repeated auditory stimuli: results from the Consortium on Genetics of Schizophrenia. Schizophr Res. 2010;119: 175-182.

10. Siegel C, Waldo M, Mizner G, et al. Deficits in sensory gating in schizophrenic patients and their relatives. Evidence obtained with auditory evoked responses. Arch Gen Psychiatry. 1984;41:607-612.

11. Bramon E, Rabe-Hesketh S, Sham P, et al. Meta-analysis of the P300 and P50 waveforms in schizophrenia. Schizophr Res. 2004;70: 315-329.

12. Onitsuka T, Oribe N, Nakamura I, et al. Review of neurophysiological findings in patients with schizophrenia. Psychiatry Clin Neurosci. 2013;67:461-470.

13. Brockhaus-Dumke A, Schultze-Lutter F, Mueller R, et al. Sensory gating in schizophrenia: P50 and N100 gating in antipsychotic-free subjects at risk, first-episode, and chronic patients. Biol Psychiatry. 2008;64:376-384.

14. Myles-Worsley M, Ord L, Blailes F, et al. P50 sensory gating in adolescents from a Pacific Island isolate with elevated risk for schizophrenia. Biol Psychiatry. 2004;55:663-667.

15. Yee CM, Williams TJ, White PM, et al. Attentional modulation of the P50 suppression deficit in recent-onset and chronic schizophrenia. J Abnorm Psychol. 2010;119:31-39.

16. Yee CM, Nuechterlein KH, Morris SE, et al. P50 suppression in recent-onset schizophrenia: clinical correlates and risperidone effects. J Abnorm Psychol. 1998;107:691-698.

17. Adler LE, Olincy A, Waldo M, et al. Schizophrenia, sensory gating, and nicotinic receptors. Schizophr Bull. 1998;24:189-202.

18. Cadenhead KS, Light GA, Shafer KM, et al. P50 suppression in individuals at risk for schizophrenia: the convergence of clinical, familial, and vulnerability marker risk assessment. Biol Psychiatry. 2005;57: 1504-1509.

19. Leonard S, Adams C, Breese CR, et al. Nicotinic receptor function in schizophrenia. Schizophr Bull. 1996;22:431-445.

20. Freedman R. The Madness Within Us: Schizophrenia as a Neuronal Process. Oxford, UK: Oxford University Press; 2010.

21. Bickford-Wimer PC, Nagamoto H, Johnson R, et al. Auditory sensory gating in hippocampal neurons: a model system in the rat. Biol Psychiatry. 1990;27:183-192. 
22. Miller CL, Freedman R. Medial septal neuron activity in relation to an auditory sensory gating paradigm. Neuroscience. 1993;55:373-380.

23. Luntz-Leybman V, Bickford PC, Freedman R. Cholinergic gating of response to auditory stimuli in rat hippocampus. Brain Res. 1992;587: $130-136$.

24. Krause M, Hoffmann WE, Hajos M. Auditory sensory gating in hippocampus and reticular thalamic neurons in anesthetized rats. Biol Psychiatry. 2003;53:244-253.

25. Esclapez M, Hirsch JC, Khazipov R, et al. Operative GABAergic inhibition in hippocampal CA1 pyramidal neurons in experimental epilepsy. Proc Natl Acad Sci U S A. 1997;94:12151-12156.

26. Seamans JK, Gorelova N, Durstewitz D, et al. Bidirectional dopamine modulation of GABAergic inhibition in prefrontal cortical pyramidal neurons. J Neurosci. 2001;21:3628-3638.

27. Homayoun $\mathrm{H}$, Moghaddam B. NMDA receptor hypofunction produces opposite effects on prefrontal cortex interneurons and pyramidal neurons. J Neurosci. 2007;27:11496-11500.

28. Klausberger T, Somogyi P. Neuronal diversity and temporal dynamics: the unity of hippocampal circuit operations. Science. 2008;321 53-57.

29. Croft RJ, Lee A, Bertolot J, et al. Associations of P50 suppression and desensitization with perceptual and cognitive features of "unreality" in schizotypy. Biol Psychiatry. 2001;50:441-446.

30. de Wilde OM, Bour LJ, Dingemans PM, et al. A meta-analysis of P50 studies in patients with schizophrenia and relatives: differences in methodology between research groups. Schizophr Res. 2007;97:137-151.

31. Yadon CA, Bugg JM, Kisley MA, et al. P50 sensory gating is related to performance on select tasks of cognitive inhibition. Cogn Affect Behav Neurosci. 2009;9:448-458.

32. Moxon KA, Gerhardt GA, Gulinello M, et al. Inhibitory control of sensory gating in a computer model of the $\mathrm{CA} 3$ region of the hippocampus. Biol Cybern. 2003;88:247-264.

33. Adler LE, Hoffer LJ, Griffith J, et al. Normalization by nicotine of deficient auditory sensory gating in the relatives of schizophrenics Biol Psychiatry. 1992;32:607-616.

34. Adler LE, Hoffer LD, Wiser A, et al. Normalization of auditory physiology by cigarette smoking in schizophrenic patients. Am J Psychiatry. 1993;150:1856-1861.

35. Stevens KE, Freedman R, Collins AC, et al. Genetic correlation of inhibitory gating of hippocampal auditory evoked response and alphabungarotoxin-binding nicotinic cholinergic receptors in inbred mouse strains. Neuropsychopharmacology. 1996;15:152-162.

36. Freedman R, Coon H, Myles-Worsley M, et al. Linkage of a neurophysiological deficit in schizophrenia to a chromosome 15 locus. Proc Natl Acad Sci U S A. 1997;94:587-592.

37. Griffith JM, O’Neill JE, Petty F, et al. Nicotinic receptor desensitization and sensory gating deficits in schizophrenia. Biol Psychiatry. 1998;44: 98-106.

38. Stevens KE, Kem WR, Mahnir VM, et al. Selective alpha7-nicotinic agonists normalize inhibition of auditory response in DBA mice. Psychopharmacology (Berl). 1998;136:320-327.

39. Leonard S, Gault J, Hopkins J, et al. Association of promoter variants in the alpha7 nicotinic acetylcholine receptor subunit gene with an inhibitory deficit found in schizophrenia. Arch Gen Psychiatry. 2002;59:1085-1096.

40. Martin LF, Freedman R. Schizophrenia and the alpha7 nicotinic acetylcholine receptor. Int Rev Neurobiol. 2007;78:225-246.

41. Martin LF, Kem WR, Freedman R. Alpha-7 nicotinic receptor agonists: potential new candidates for the treatment of schizophrenia. Psychopharmacology (Berl). 2004;174:54-64.

42. Brinkman MJ, Stauder JE. Development and gender in the P50 paradigm. Clin Neurophysiol. 2007;118:1517-1524.

43. Young JW, Geyer MA. Evaluating the role of the alpha-7 nicotinic acetylcholine receptor in the pathophysiology and treatment of schizophrenia. Biochem Pharmacol. 2013;86:1122-1132.

44. Freedman R. alpha7-nicotinic acetylcholine receptor agonists for cognitive enhancement in schizophrenia. Annu Rev Med. 2014;65: 245-261.
45. Baker NJ, Staunton M, Adler LE, et al. Sensory gating deficits in psychiatric inpatients: relation to catecholamine metabolites in different diagnostic groups. Biol Psychiatry. 1990;27:519-528.

46. Waldo M, Gerhardt G, Baker N, et al. Auditory sensory gating and catecholamine metabolism in schizophrenic and normal subjects. Psychiatry Res. 1992;44:21-32.

47. Adler LE, Hoffer L, Nagamoto HT, et al. Yohimbine impairs P50 auditory sensory gating in normal subjects. Neuropsychopharmacology. 1994;10:249-257.

48. Hammer TB, Oranje B, Glenthoj BY. The effects of imipramine on P50 suppression, prepulse inhibition and habituation of the startle response in humans. Int J Neuropsychopharmacol. 2007;10:787-795.

49. Oranje B, Glenthoj BY. Clonidine normalizes levels of P50 gating in patients with schizophrenia on stable medication. Schizophr Bull. Epub 2013 October 8.

50. Galazyuk AV, Feng AS. Encoding of sound duration by neurons in the auditory cortex of the little brown bat, Myotis lucifugus. $J$ Comp Physiol A. 1997;180:301-311.

51. Tan AY, Zhang LI, Merzenich MM, et al. Tone-evoked excitatory and inhibitory synaptic conductances of primary auditory cortex neurons. J Neurophysiol. 2004;92:630-643.

52. Wehr M, Zador AM. Synaptic mechanisms of forward suppression in rat auditory cortex. Neuron. 2005;47:437-445.

53. Fritz J, Shamma S, Elhilali M. One click, two clicks: the past shapes the future in auditory cortex. Neuron. 2005;47:325-327.

54. Smith DM, Grant B, Fisher DJ, et al. Auditory verbal hallucinations in schizophrenia correlate with P50 gating. Clin Neurophysiol. 2013;124: 1329-1335.

55. Miller CL, Freedman R. The activity of hippocampal interneurons and pyramidal cells during the response of the hippocampus to repeated auditory stimuli. Neuroscience. 1995;69:371-381.

56. Mears RP, Klein AC, Cromwell HC. Auditory inhibitory gating in medial prefrontal cortex: single unit and local field potential analysis. Neuroscience. 2006;141:47-65.

57. Volkov IO, Galazyuk AV. Peculiarities of inhibition in cat auditory cortex neurons evoked by tonal stimuli of various durations. Exp Brain Res. 1992;91:115-120.

58. Merzenich MM, Schreiner C, Jenkins W, et al. Neural mechanisms underlying temporal integration, segmentation, and input sequence representation: some implications for the origin of learning disabilities. Ann N Y Acad Sci. 1993;682:1-22.

59. Wehr M, Zador AM. Balanced inhibition underlies tuning and sharpens spike timing in auditory cortex. Nature. 2003;426:442-446.

60. Freedman R, Waldo M, Bickford-Wimer P, et al. Elementary neuronal dysfunctions in schizophrenia. Schizophr Res. 1991;4:233-243.

61. Freedman R, Adler LE, Myles-Worsley M, et al. Inhibitory gating of an evoked response to repeated auditory stimuli in schizophrenic and normal subjects. Human recordings, computer simulation, and an animal model. Arch Gen Psychiatry. 1996;53:1114-1121.

62. Boutros NN, Belger A. Midlatency evoked potentials attenuation and augmentation reflect different aspects of sensory gating. Biol Psychiatry. 1999;45:917-922.

63. Vinogradova OS. Hippocampus as comparator: role of the two input and two output systems of the hippocampus in selection and registration of information. Hippocampus. 2001;11:578-598.

64. Sakai M, Chimoto S, Qin L, et al. Neural mechanisms of interstimulus interval-dependent responses in the primary auditory cortex of awake cats. BMC Neurosci. 2009;10:10.

65. Du X, Jansen BH. A neural network model of normal and abnormal auditory information processing. Neural Netw. 2011;24:568-574.

66. Boutros NN, Gjini K, Eickhoff SB, et al. Mapping repetition suppression of the P50 evoked response to the human cerebral cortex. Clin Neurophysiol. 2013;124:675-685.

67. Korzyukov O, Pflieger ME, Wagner M, et al. Generators of the intracranial P50 response in auditory sensory gating. Neuroimage. 2007;35: 814-826.

68. Simons JS, Spiers HJ. Prefrontal and medial temporal lobe interactions in long-term memory. Nat Rev Neurosci. 2003;4:637-648. 
69. Geyer MA, Braff DL. Startle habituation and sensorimotor gating in schizophrenia and related animal models. Schizophr Bull. 1987; 13:643-668.

70. Duncan CC. Event-related brain potentials: a window on information processing in schizophrenia. Schizophr Bull. 1988;14:199-203.

71. Braff DL, Geyer MA. Sensorimotor gating and schizophrenia. Human and animal model studies. Arch Gen Psychiatry. 1990;47:181-188.

72. Grillon C, Courchesne E, Ameli R, et al. Increased distractibility in schizophrenic patients. Electrophysiologic and behavioral evidence. Arch Gen Psychiatry. 1990;47:171-179.

73. Karper LP, Freeman GK, Grillon C, et al. Preliminary evidence of an association between sensorimotor gating and distractibility in psychosis. J Neuropsychiatry Clin Neurosci. 1996;8:60-66.

74. Silverstein SM, Keane BP. Perceptual organization impairment in schizophrenia and associated brain mechanisms: review of research from 2005 to 2010. Schizophr Bull. 2011;37:690-699.

75. Rajji TK, Miranda D, Mulsant BH. Cognition, function, and disability in patients with schizophrenia: a review of longitudinal studies. Can J Psychiatry. 2014;59:13-17.

76. Shakow D. Psychological deficit in schizophrenia. Behav Sci. 1963;8: 275-305.

77. Venables PH. Selectivity of attention, withdrawal, and cortical activation. Studies in chronic schizophrenia. Arch Gen Psychiatry. 1963;9: 74-78.

78. Braff DL, Grillon C, Geyer MA. Gating and habituation of the startle reflex in schizophrenic patients. Arch Gen Psychiatry. 1992;49: 206-215.

79. Hetrick WP, Erickson MA, Smith DA. Phenomenological dimensions of sensory gating. Schizophr Bull. 2012;38:178-191.

80. Hu L, Boutros NN, Jansen BH. Sensory gating-out and gating-in in normal and schizophrenic participants. Clin EEG Neurosci. 2012;43: 23-31.

81. Ji B, Mei W, Zhang JX, et al. Abnormal auditory sensory gating-out in first-episode and never-medicated paranoid schizophrenia patients: an fMRI study. Exp Brain Res. 2013;229:139-147.

82. Smucny J, Olincy A, Eichman LC, et al. Early sensory processing deficits predict sensitivity to distraction in schizophrenia. Schizophr Res. 2013;147:196-200.

83. Freedman R, Adler LE, Waldo M. Gating of the auditory evoked potential in children and adults. Psychophysiology. 1987;24:223-227.

84. Zhang XY, Liu L, Liu S, et al. Short-term tropisetron treatment and cognitive and P50 auditory gating deficits in schizophrenia. Am J Psychiatry. 2012;169:974-981.

85. Deutsch SI, Schwartz BL, Schooler NR, et al. Targeting alpha-7 nicotinic neurotransmission in schizophrenia: a novel agonist strategy. Schizophr Res. 2013;148:138-144.

86. Hahn B, Gold JM, Buchanan RW. The potential of nicotinic enhancement of cognitive remediation training in schizophrenia. Neuropharmacology. 2013;64:185-190.

87. Taly A. Novel approaches to drug design for the treatment of schizophrenia. Expert Opin Drug Discov. 2013;8:1285-1296.

88. Adler LE, Cawthra EM, Donovan KA, et al. Improved P50 auditory gating with ondansetron in medicated schizophrenia patients. Am J Psychiatry. 2005;162:386-388.

89. Koike K, Hashimoto K, Takai N, et al. Tropisetron improves deficits in auditory P50 suppression in schizophrenia. Schizophr Res. 2005;76: 67-72.

90. Callaway E, 3rd, Jones RT, Layne RS. Evoked responses and segmental set of schizophrenia. Arch Gen Psychiatry. 1965;12:83-89.

91. Shakow D. Segmental set. The adaptive process in schizophrenia. Am Psychol. 1977;32:129-139.

92. Javitt DC. When doors of perception close: bottom-up models of disrupted cognition in schizophrenia. Annu Rev Clin Psychol. 2009;5: 249-275.

93. Leitman DI, Sehatpour P, Higgins BA, et al. Sensory deficits and distributed hierarchical dysfunction in schizophrenia. Am J Psychiatry. 2010;167:818-827.
94. Williams LE, Blackford JU, Luksik A, et al. Reduced habituation in patients with schizophrenia. Schizophr Res. 2013;151:124-132.

95. Adler LE, Pachtman E, Franks RD, et al. Neurophysiological evidence for a defect in neuronal mechanisms involved in sensory gating in schizophrenia. Biol Psychiatry. 1982;17:639-654.

96. Adler LE, Olincy A, Cawthra EM, et al. Varied effects of atypical neuroleptics on P50 auditory gating in schizophrenia patients. Am J Psychiatry. 2004;161:1822-1828.

97. Freedman R, Adler LE, Waldo MC, et al. Neurophysiological evidence for a defect in inhibitory pathways in schizophrenia: comparison of medicated and drug-free patients. Biol Psychiatry. 1983;18: 537-551.

98. Baker N, Adler LE, Franks RD, et al. Neurophysiological assessment of sensory gating in psychiatric inpatients: comparison between schizophrenia and other diagnoses. Biol Psychiatry. 1987;22: 603-617.

99. Judd LL, McAdams L, Budnick B, et al. Sensory gating deficits in schizophrenia: new results. Am J Psychiatry. 1992;149: 488-493.

100. Clementz BA, Blumenfeld LD, Cobb S. The gamma band response may account for poor P50 suppression in schizophrenia. Neuroreport. 1997;8:3889-3893.

101. Boutros NN, Belger A, Campbell D, et al. Comparison of four components of sensory gating in schizophrenia and normal subjects: a preliminary report. Psychiatry Res. 1999;88:119-130.

102. Boutros NN, Korzyukov O, Jansen B, et al. Sensory gating deficits during the mid-latency phase of information processing in medicated schizophrenia patients. Psychiatry Res. 2004;126:203-215.

103. Light GA, Geyer MA, Clementz BA, et al. Normal P50 suppression in schizophrenia patients treated with atypical antipsychotic medications. Am J Psychiatry. 2000;157:767-771.

104. Patterson JV, Jin Y, Gierczak M, et al. Effects of temporal variability on P50 and the gating ratio in schizophrenia: a frequency domain adaptive filter single-trial analysis. Arch Gen Psychiatry. 2000;57: 57-64.

105. Myles-Worsley M. P50 sensory gating in multiplex schizophrenia families from a Pacific Island isolate. Am J Psychiatry. 2002;159: 2007-2012.

106. Hong LE, Summerfelt A, McMahon RP, et al. Gamma/beta oscillation and sensory gating deficit in schizophrenia. Neuroreport. 2004;15: $155-159$.

107. Ringel TM, Heidrich A, Jacob CP, et al. Sensory gating deficit in a subtype of chronic schizophrenic patients. Psychiatry Res. 2004;125: 237-245.

108. Johannesen JK, Kieffaber PD, O’Donnell BF, et al. Contributions of subtype and spectral frequency analyses to the study of P50 ERP amplitude and suppression in schizophrenia. Schizophr Res. 2005;78: 269-284.

109. Louchart-de la Chapelle S, Levillain D, Menard JF, et al. P50 inhibitory gating deficit is correlated with the negative symptomatology of schizophrenia. Psychiatry Res. 2005;136:27-34.

110. Price GW, Michie PT, Johnston J, et al. A multivariate electrophysiological endophenotype, from a unitary cohort, shows greater research utility than any single feature in the Western Australian family study of schizophrenia. Biol Psychiatry. 2006;60:1-10.

111. Thoma RJ, Hanlon FM, Miller GA, et al. Neuropsychological and sensory gating deficits related to remote alcohol abuse history in schizophrenia. J Int Neuropsychol Soc. 2006;12:34-44.

112. Jansen BH, Hu L, Boutros NN. Auditory evoked potential variability in healthy and schizophrenia subjects. Clin Neurophysiol. 2010;121: 1233-1239.

113. Sanchez-Morla EM, Garcia-Jimenez MA, Barabash A, et al. P50 sensory gating deficit is a common marker of vulnerability to bipolar disorder and schizophrenia. Acta Psychiatr Scand. 2008;117:313-318.

114. Devrim-Ucok M, Keskin-Ergen HY, Ucok A. P50 gating at acute and post-acute phases of first-episode schizophrenia. Prog Neuropsychopharmacol Biol Psychiatry. 2008;32:1952-1956. 
115. Chang WP, Arfken CL, Sangal MP, et al. Probing the relative contribution of the first and second responses to sensory gating indices: a meta-analysis. Psychophysiology. 2011;48:980-992.

116. Sanchez-Morla EM, Santos JL, Aparicio A, et al. Neuropsychological correlates of P50 sensory gating in patients with schizophrenia. Schizophr Res. 2013;143:102-106.

117. Magnee MJ, Oranje B, van Engeland H, et al. Cross-sensory gating in schizophrenia and autism spectrum disorder: EEG evidence for impaired brain connectivity? Neuropsychologia. 2009; 47:1728-1732.

118. Traub RD, Whittington MA, Stanford IM, et al. A mechanism for generation of long-range synchronous fast oscillations in the cortex. Nature. 1996;383:621-624.

119. Traub RD, Whittington MA, Buhl EH, et al. On the mechanism of the gamma $->$ beta frequency shift in neuronal oscillations induced in rat hippocampal slices by tetanic stimulation. J Neurosci. 1999;19: 1088-1105.

120. Kopell N, Ermentrout GB, Whittington MA, et al. Gamma rhythms and beta rhythms have different synchronization properties. Proc Natl Acad Sci U S A. 2000;97:1867-1872.

121. Bibbig A, Faulkner HJ, Whittington MA, et al. Self-organized synaptic plasticity contributes to the shaping of gamma and beta oscillations in vitro. J Neurosci. 2001;21:9053-9067.

122. Haenschel C, Baldeweg T, Croft RJ, et al. Gamma and beta frequency oscillations in response to novel auditory stimuli: a comparison of human electroencephalogram (EEG) data with in vitro models. Proc Natl Acad Sci U S A. 2000;97:7645-7650.
123. Engel AK, Fries P, Singer W. Dynamic predictions: oscillations and synchrony in top-down processing. Nat Rev Neurosci. 2001;2: 704-716.

124. Fries P. A mechanism for cognitive dynamics: neuronal communication through neuronal coherence. Trends Cogn Sci. 2005;9:474-480.

125. Fries P, Nikolic D, Singer W. The gamma cycle. Trends Neurosci. 2007;30:309-316.

126. Fuchs EC, Doheny H, Faulkner H, et al. Genetically altered AMPAtype glutamate receptor kinetics in interneurons disrupt long-range synchrony of gamma oscillation. Proc Natl Acad Sci U S A. 2001;98: 3571-3576.

127. Lewis DA, Hashimoto T, Volk DW. Cortical inhibitory neurons and schizophrenia. Nat Rev Neurosci. 2005;6:312-324.

128. Gonzalez-Burgos G, Lewis DA. GABA neurons and the mechanisms of network oscillations: implications for understanding cortical dysfunction in schizophrenia. Schizophr Bull. 2008;34:944-961.

129. Mulert C, Kirsch V, Pascual-Marqui R, et al. Long-range synchrony of gamma oscillations and auditory hallucination symptoms in schizophrenia. Int J Psychophysiol. 2011;79:55-63.

130. McNally JM, McCarley RW, Brown RE. Impaired GABAergic neurotransmission in schizophrenia underlies impairments in cortical gamma band oscillations. Curr Psychiatry Rep. 2013;15:346.
Neuropsychiatric Disease and Treatment

\section{Publish your work in this journal}

Neuropsychiatric Disease and Treatment is an international, peerreviewed journal of clinical therapeutics and pharmacology focusing on concise rapid reporting of clinical or pre-clinical studies on a range of neuropsychiatric and neurological disorders. This journal is indexed on PubMed Central, the 'PsycINFO' database and CAS,

\section{Dovepress}

and is the official journal of The International Neuropsychiatric Association (INA). The manuscript management system is completely online and includes a very quick and fair peer-review system, which is all easy to use. Visit http://www.dovepress.com/testimonials.php to read real quotes from published authors. 